\title{
Experiences of discrimination: Validity and reliability of a self-report measure for population health research on racism and health
}

\author{
Nancy Krieger ${ }^{\mathrm{a}, *}$, Kevin Smith ${ }^{\mathrm{b}, 1}$, Deepa Naishadham ${ }^{\mathrm{b}}$, Cathy Hartman ${ }^{\mathrm{c}}$, \\ Elizabeth M. Barbeau ${ }^{\text {d }}$ \\ ${ }^{a}$ Harvard School of Public Health, Department of Society, Human Development, and Health, 677 Huntington Avenue, \\ Boston, MA 02115, USA \\ ${ }^{\mathrm{b}}$ New England Research Institute, 9 Galen Street, Watertown, MA 02472, USA \\ ${ }^{\mathrm{c}}$ Dana-Farber Cancer Institute, 44 Binney Street, Boston, MA 02115, USA \\ ${ }^{\mathrm{d}}$ Center for Community-Based Research, Dana-Farber Cancer Institute,44 Binney Street, Boston, MA 02115, USA
}

Available online 21 April 2005

\begin{abstract}
Population health research on racial discrimination is hampered by a paucity of psychometrically validated instruments that can be feasibly used in large-scale studies. We therefore sought to investigate the validity and reliability of a short self-report instrument, the "Experiences of Discrimination" (EOD) measure, based on a prior instrument used in the Coronary Artery Risk Development in Young Adults (CARDIA) study.

Study participants were drawn from a cohort of working class adults, age 25-64, based in the Greater Boston area, Massachusetts (USA). The main study analytic sample included 159 black, 249 Latino, and 208 white participants; the validation study included 98 African American and 110 Latino participants who completed a re-test survey two to four weeks after the initial survey. The main and validation survey instruments included the EOD and several single-item discrimination questions; the validation survey also included the Williams Major and Everyday discrimination measures.

Key findings indicated the EOD can be validly and reliably employed. Scale reliability was high, as demonstrated by confirmatory factor analysis, Cronbach's alpha (0.74 or greater), and test-re-test reliability coefficients $(0.70)$. Structural equation modeling demonstrated the EOD had the highest correlation $(r=0.79)$ with an underlying discrimination construct compared to other self-report discrimination measures employed. It was significantly associated with psychological distress and tended to be associated with cigarette smoking among blacks and Latinos, and it was not associated with social desirability in either group. By contrast, single-item measures were notably less reliable and had low correlations with the multi-item measures. These results underscore the need for using validated, multi-item measures of experiences of racial discrimination and suggest the EOD may be one such measure that can be validly employed with working class African Americans and Latino Americans.
\end{abstract}

(C) 2005 Elsevier Ltd. All rights reserved.

Keywords: Racial discrimination; Validity; Reliability; Psychometric; Black; Latino; USA

\footnotetext{
*Corresponding author. Tel.: + 1617432 1571; fax: + 16174323123 .

E-mail addresses: nkrieger@hsph.harvard.edu (N. Krieger), kevinsmith@rti.org (K. Smith), dnaishadham@neri.org (D. Naishadham), cathy_hartman@dfci.harvard.edu (C. Hartman), elizabeth_barbeau@dfci.harvard.edu (E.M. Barbeau).

${ }^{1}$ Now at: Research Triangle Institute, USA.
} 


\section{Introduction}

Although the idea that racial injustice harms health has appeared in the public health and medical literature since the 18th century (Krieger, 2000; Banton, 1998; Byrd \& Clayton, 2000; Willie, Kramer, \& Brown, 1973), research on specific measures that could be used in empirical health research is more recent. During the 1960 s and 1970s, a variety of measures were introduced into the psychological literature, concerned with understanding the impact of racism on mental health (Barbarin, Good, Pharr, \& Siskind, 1981) and evaluating the US Army's "racial climate" (Hiett et al., 1978). Social science research likewise began to explore assessing how racial discrimination restricts opportunities for employment, housing, and education (Blank, Dabady, \& Citro, 2004). It was not until the 1990s, however, that a small but growing number of public health studies, both quantitative and qualitative, began to investigate explicitly associations of self-reported experiences of racial discrimination with somatic and also mental health (reviewed in Krieger, Rowley, Herman, Avery, \& Phillips, 1993; Krieger, 2000; Williams, Neighbors, \& Jackson, 2003), with additional work focused on racial discrimination in the provision of health care (Smedley, Stith, \& Nelson, 2003).

For population health research to contribute meaningfully to understand links between racial discrimination and health, studies need valid and reliable measures that can feasibly be used in large-scale population-based studies. Yet, because work in this area is in its infancy, the field is hampered by an important problem: a paucity of instruments whose psychometric properties have been rigorously assessed (Krieger, 2000; Williams et al., 2003; Blank et al., 2004). Moreover, to the extent psychometric validation studies have been done, they have been conducted principally among US black participants, mostly recruited from university students, faculty, and staff (Utsey, 1998; Landrine \& Klonoff, 1996; McNeilly et al., 1996; Vines et al., 2001). Whether these measures can be used among working class and low income African Americans, or among other racial/ ethnic groups, remains unknown and is a salient question, given their concentration among persons with less education and low-wage jobs (Smith, 2001).

The objectives of our study were thus to investigate, within a US study population comprised of African American, Latino, and white working class participants, the validity and reliability of a short self-report instrument to measure exposure to racial discrimination. The selected instrument, which we call the "Experiences of Discrimination" (EOD) measure, is based on a prior instrument developed by Krieger (1990), used in the Coronary Artery Risk Development in Young Adults (CARDIA) study (Krieger \& Sidney, 1996) and in other epidemiologic investigations (e.g., Yen, Ragland,
Greiner, \& Fisher, 1999; Stancil, Hertz-Picciotto, Schramm, \& Watt-Morse, 2000; Stuber, Galea, Ahern, Blaney, \& Fuller, 2003; Dole et al., 2004). To aid investigation of the EODs validity, we also employed the Major and Everyday discrimination measure developed by Williams (Williams, Yu, Jackson, \& Anderson, 1997), plus several single-item questions.

\section{Methods}

\section{Study population}

Study participants were drawn from a cohort of working adults, age 25-64, recruited for United for Health, a study of the health impacts of physical and social hazards at work among union members employed in a variety of manufacturing and retail sites located in or near Boston, Massachusetts (USA). The validation study was designed to recruit the first 100 African American and first 100 Latino workers who agreed to participate in the main and validation survey, thereby ensuring adequate sample size $(n=200)$ for factor analysis (MacCallum, Widaman, Preacher, \& Hong, 2001; Boomsma \& Hoogland, 2001). Recruitment for the validation study occurred from March 2003 through March 2004; recruitment for the main study continued through August 2004.

\section{Study protocol}

Study staff worked with the leadership of the selected unions and management of participating worksites to design the recruitment protocol. Permission of management was required to gain entry to the worksites. Management, union, and the funders did not have access to study data, nor did management or funders have any role in the collection, analysis, or interpretation of the data or preparation, review, or approval of the study's scientific papers. All participants received an informed consent reference sheet and provided verbal informed consent; conduct of the study was approved by the Human Subjects Committees of the Harvard School of Public Health and the Dana-Farber Cancer Institute.

Fig. 1 delineates the recruitment and interview protocol, including eligibility criteria, incentives, and participation rates. Briefly, workers were screened and recruited on-site by study staff, after having been sent an introductory letter, based on a list of union members by worksite. The main survey was administered on-site, typically during work hours, in a private room, and consisted of a 40-45 min survey, administered by computer (in either English or Spanish), followed by a 15-min health check. We used Audio-Computer Assisted Self-Interviewing (ACASI) both to improve likelihood of obtaining sensitive information and to enable persons 
Participants

Initial sample

Validation

study

Key informant

study
Recruitment and survey protocol

Recruitment pool: list of union members, by worksite

Eligible: $25-64$ years old; employed at worksite 2+ months; English or Spanish
Participation rates

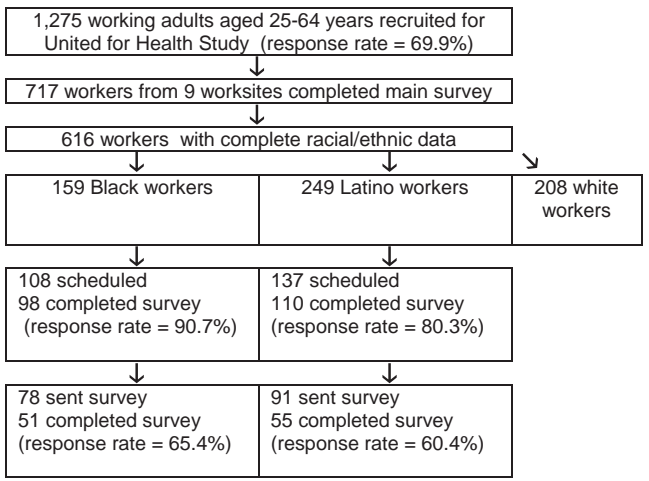

Fig. 1. Recruitment protocol and participation rates for the main, validation, and key informant studies, United for Health, Greater Boston area, MA, 2004.

with low literacy to respond (Office of Applied Studies, 2001). With ACASI, questions shown on the screen are also read out-loud, over a headphone, via the digitally recorded audio component; participants respond by pressing the indicated keys on a masked keyboard. The Spanish version of the survey was translated from English and then back-translated to ensure accuracy. One or more of the interview staff were bilingual in English and Spanish and were available to answer participants' questions.

Eligible participants who agreed to be part of the validation study and who met the screening eligibility criteria took the ACASI re-test survey (in either English or Spanish) between two and four weeks after the initial survey. Participation was restricted to workers who identified as being either: (a) African American, born in the US, with at least 1 parent born in the US, or (b) Latino. These criteria were employed to distinguish between African Americans with a family history in the US and other black Americans who immigrated from or were 1st generation immigrants from diverse Caribbean or African nations, since research indicates that perceptions, experiences, and responses to racial discrimination in the US may differ across these groups (Waters, 1999; Williams \& Jackson, 2000). At the conclusion of re-test survey, participants were asked to provide contact information for a key informant who was knowledgeable about their experiences of discrimination. These key informants were contacted by mail and sent a questionnaire to fill out, plus a self-addressed stamped envelope for return.

\section{Sociodemographic variables}

All sociodemographic data on race/ethnicity, gender, age, socioeconomic position, and country of birth of the participants and of their parents were based on self-report. Language of survey administration was tracked. For the validation study, the handful of participants under age $25(n=2)$ and age 65 and older $(n=17)$ were retained, as were the 6 black participants who self-identified as being eligible for the validation study, based on the screening interview, but who in the survey indicated that both of their parents were born outside of the US, as were 3 of these participants themselves.

Extensive socioeconomic data were obtained on job characteristics and economic resources. In this study we report on the type of firm in which the participants worked, plus their occupational class, hourly wage, household poverty level, and highest level of education completed. In 2003, the US federal poverty line for a household of 2 adults and 2 children equaled \$18,660 (US Census Bureau, 2004). Wages were categorized in relation to the estimated living wage for the Boston area, equal to $\$ 10.54 / \mathrm{h}$ in 2003 (Association of Community Organizations for Reform Now, 2004).

\section{Measures of self-reports of racial discrimination and response to unfair treatment}

The main survey included the EOD questionnaire (Appendix 1), based on the prior closed-format questions developed by Krieger (1990) and used in the CARDIA study (Krieger \& Sidney, 1996). The CARDIA version asked about having ever experienced discrimination in each of seven specified situations, and also about responses to unfair treatment. This instrument is conceptualized as measuring "self-reported experiences of discrimination," not "perceived discrimination," because while self-reported experiences must be 
perceived, not all perceived experiences are necessarily reported, depending upon individuals' willingness or ability to report them (Krieger, 2000). The revised version, used in this study, newly asked about the frequency of occurrence, plus added two situations ("getting service in a store or restaurant," and "getting credit, bank loans, or a mortgage"). The "situation" version was scored by counting the number of situations in which a participant reported experiencing racial discrimination. The "frequency" version measured total occurrences, assigning the value of 0 to "never," 1 to "once," 2.5 to " $2-3$ times," and 5 to " 4 or more times," and summed across items. Response to unfair treatment was scored as engaged (response $=$ "do something (act)/ talk to others (talk)"; score $=2$ ), moderate (respon$\mathrm{se}=$ "act $/ \mathrm{keep}$ to self (quiet)" or "accept/talk"; score $=1$ ), or passive (response = "accept/quiet"; score $=0)($ Stancil et al., 2000).

Also included were: (a) "worry" questions, about how much participants worried about racial discrimination as a child and in the past year, personally and for their racial/ethnic group; (b) global questions on how often participants felt members of their racial/ethnic group and themselves personally experience racial discrimination; and (c) a question about filing a formal complaint because of racial discrimination (Appendix 1). A five-item social desirability scale (Hays, 1989) was likewise included to gauge its impact on responses to questions about discrimination. To minimize problems of order effects, participants were randomly assigned different versions of the main and repeat surveys, with questions differently ordered within the discrimination section.

The re-test survey included the same discrimination questions asked in the main survey, plus the Williams Major and Everyday discrimination questions (Appendix 1). The Major questions pertain to nine situations; for each one, participants are asked if they have experienced unfair treatment and, if so, which of 11 options ("ancestry or national origin"; "gender"; "race"; "age"; "religion"; "height or weight"; "shade of skin color"; "sexual orientation"; "physical disability"; "other") was the "main reason for this experience." Following prior usage (Williams, Neighbors, \& Jackson, 1997), the summary score was a count of the number of situations for which participants reported having experienced the unfair treatment for a racial reason.

The Everyday questions asked participants to indicate how often they had been treated badly in 10 situations; participants who experienced such treatment at least once in at least one of the situations were then asked to select among 11 options to indicate the main reason for "this/these experiences," overall. Recognizing this measure has been scored as both a unidimensional scale (Williams et al., 1997; Kessler, Michelson, \& Williams, 1999) and a two-factor scale (Guyll, Matthews, \&
Bromberger, 2001), we conducted an exploratory factor analysis, found that all items had their highest loadings on the first factor, and therefore used the conventional scoring approach of counting the number of situations for which participants reported having experienced unfair treatment among those attributing a racial reason as the overall main reason for the selected experiences.

Finally, the key informant survey closed-format queries were modeled on the EOD and the other discrimination questions in the main survey. Additional questions asked the key informants how they knew the participants and for how long.

\section{Health outcomes}

As an additional check on the EODs validity, we assessed its association with two health outcomes previously shown to be correlated with self-reported experiences of racial discrimination: (a) psychological distress (Kessler et al., 1999; Williams \& WilliamsMorris, 2000) and (b) smoking (Landrine \& Klonoff, 2000; Guthrie, Young, Williams, Boyd, \& Kintner, 2002). Psychological distress was measured using a sixitem instrument validated by Kessler et al. (2002). "Ever smokers" were defined as persons who reported they had ever smoked at least 100 cigarettes (Trosclair, Husten, Pederson, \& Dhillon, 2002).

\section{Statistical analysis}

The main study analytic sample $(N=616)$ was restricted to participants who identified as either black ( $N=159)$, Latino $(N=249)$, or white (non- Hispanic) $(N=208)$; among them were 98 African American and 110 Latino validation study participants, for whom data were obtained for $107 \mathrm{key}$ informants. We examined the distribution of sociodemographic characteristics and the response patterns for the items in all of the scales. When multiple items were unanswered, we set the scale to missing. When reasons for discrimination were not provided for the Williams items, instead of excluding the case as missing, we scored the partial responses conservatively by assuming the situation was not the result of racial discrimination.

We then specified a series of three structural equation models (SEMs), estimated using LISREL 8.5 (Joreskog $\&$ Sorbom, 1993) to explore the structure of the different measures of discrimination. First, using data from the main study, we tested a confirmatory factor model of the nine EOD items. Second, we tested the EOD items for differential item functioning (DIF) among respondents in the main study. DIF occurs when members of a particular group give responses to specific items that are higher or lower than would be expected on the basis of their underlying trait level; if present, it can lead to 
biased comparison of scale scores. We used the multipleindicator multiple-cause (MIMIC) approach (Fleishman \& Lawrence, 2003) with age, gender, educational attainment, racial/ethnic group, place of birth, and social desirability as potential sources of DIF. Language of survey administration was not included because of its high correlation with both race/ethnicity $(r=0.81)$ and place of birth $(r=0.65)$. We estimated a no-DIF base model (no direct effects of covariates on individual items after adjusting for the latent trait) and examined modification indices for evidence of DIF.

Third, among the validation study participants, we tested a validation model consisting of the various discrimination measures (scales and global questions) to determine if they were all tapping the same underlying construct. The fit of these SEMs was evaluated by the Comparative Fit Index (CFI) and the Root Mean Square Error of Approximation (RMSEA).

Scale reliability was assessed by Cronbach's alpha and, for the EOD items, by test-re-test correlations between the main study and validation study administrations. All analyses other than the SEMs were conducted in SAS (SAS Institute, 2001).

\section{Results}

\section{Sociodemographic characteristics}

Table 1 presents data on the sociodemographic characteristics of the main $(n=616)$ and validation ( $n=208$ ) study populations. Within the main study, the 159 black, 249 Latino, and 208 white participants were, on average, in their late $30 \mathrm{~s}$ to early $40 \mathrm{~s}$, evenly split among women and men, and mainly working class nonsupervisory employees; $60-80 \%$ had completed at most a high school education or its equivalent. Despite being predominantly union members, $53 \%$ earned less than a living wage $(\$ 6.00-\$ 10.54 / \mathrm{h})$ and $42 \%$ lived in poverty, with such economic hardship 1.7-2 times more likely to affect the black and Latino as compared to the white workers. One-quarter of the black and three-quarters of the Latino participants were foreign-born. African American and Latino participants in the validation study closely resembled those in the main survey, except as planned regarding nativity for the former.

\section{EOD: main study results}

Data on the EOD for the 616 main study participants are provided in Table 2; only $4 \%$ of participants gave incomplete responses. Analyses based on the 9- and 7item versions of the EOD yielded similar results, as did analyses for the situation and frequency versions of this measure. Suggesting good internal reliability, Cronbach's alpha for the 9-item version for all groups was
0.74 or higher; similar results were obtained for the 7 item version. As expected, EOD values were highest for the black, somewhat lower for the Latino, and much lower for the white participants; by contrast, within all three groups a similar proportion (6-9\%) reported having filed a formal complaint about racial discrimination. Summary scores for responses to unfair treatment were also similar.

All of the EOD items for frequency of discrimination were positively correlated, with inter-item correlations ranging from 0.14 to 0.53 . The confirmatory factor analysis identified three correlated error variances, including those for the two most common situations ("on the street" and "in stores"), and also between the "getting hired" and "at work" items. With the inclusion of these correlated variances, the model produced an acceptable fit to the data for a single underlying factor $(\mathrm{CFI}=0.935 ; \quad \mathrm{RMSEA}=0.080)$. Factor loadings ranged from 0.47 to 0.72 ; all loadings were highly significant.

Fig. 2 shows the model for the DIF analysis, in which EOD is a latent variable. Four findings stand out. First, the no-DIF specification provided an excellent fit to the data $(\mathrm{CFI}=0.935$; RMSEA $=0.054)$. Of the 63 possible DIF effects, only one path had a modification index exceeding 10 (black participants were more likely than expected to report discrimination for store service), but this had no impact on the fit of the model. The overall pattern indicated that no group-specific bias was present in the item responses. Second, scores on the latent variables were significantly higher for the black ( $\beta=0.40)$ and Latino $(\beta=0.25)$ compared to the white participants. They were also significantly lower for women compared to men $(\beta=-0.17)$ and for person born outside of the US $(\beta=-0.19)$. Third, EOD levels were not influenced by social desirability, age, or educational attainment. Fourth, the model confirmed the prior analysis of the structure of the EOD scale, with factor loadings for individual items ranging from 0.49 to 0.73 .

\section{Validation study results}

\section{Univariate analyses}

Results for the EOD, including Cronbach's alpha, and for filing a formal complaint were similar for the main and validation study analyses (Table 3), with one exception: self-reports of discrimination (especially "from the police and in the courts") and of filing a formal complaint were greater for the African American validation participants compared to black main survey participants. Both Williams' measures likewise indicated higher levels of self-reported racial discrimination for the African American compared to the Latino participants, as did the "worry" and "global" questions. 
Table 1

Sociodemographic characteristics of the main $(n=616)$ and validation $(n=208)$ study populations: United for Health cohort, Greater Boston area, MA, 2004

\begin{tabular}{|c|c|c|c|c|c|c|}
\hline \multirow[t]{2}{*}{ Characteristic } & \multirow[t]{2}{*}{ Missing (\%) } & \multicolumn{2}{|l|}{ Black } & \multicolumn{2}{|l|}{ Latino } & \multirow{2}{*}{$\begin{array}{l}\text { White }(\%) \\
(n=208)\end{array}$} \\
\hline & & $\begin{array}{l}\text { Main }(\%) \\
(n=159)\end{array}$ & $\begin{array}{l}\text { Validation } \\
(\%)(n=98)\end{array}$ & $\begin{array}{l}\text { Main }(\%) \\
(n=249)\end{array}$ & $\begin{array}{l}\text { Validation } \\
(\%)(n=110)\end{array}$ & \\
\hline Age: & 4.7 & & & & & \\
\hline$<25$ years & & 0.0 & 0.0 & 0.9 & 0.0 & 0.0 \\
\hline 25-44 years & & 63.2 & 58.8 & 67.7 & 72.9 & 47.0 \\
\hline 45-64 years & & 35.5 & 40.2 & 30.6 & 26.2 & 46.5 \\
\hline$\geqslant 65$ years & & 1.3 & 1.0 & 0.9 & 0.9 & 6.5 \\
\hline Gender: & 0.8 & & & & & \\
\hline Women & & 57.2 & 59.1 & 44.9 & 43.5 & 40.0 \\
\hline Men & & 41.8 & 40.8 & 55.1 & 56.5 & 60.0 \\
\hline Type of worksite: & 0.0 & & & & & \\
\hline Manufacturing & & 6.3 & 0 & 78.3 & 61.8 & 22.6 \\
\hline Retail & & 93.7 & 100.0 & 21.7 & 38.2 & 77.4 \\
\hline Currently a union member: & 1.3 & & & & & \\
\hline Yes & & 91.2 & 91.8 & 74.9 & 79.6 & 96.1 \\
\hline No & & 8.8 & 8.2 & 25.1 & 20.4 & 3.9 \\
\hline Parents nativity: & 4.5 & & & & & \\
\hline One or both parents born in US & & 71.3 & 96.9 & 13.8 & 15.5 & 85.0 \\
\hline Both parents born out of US & & 28.7 & 3.1 & 86.2 & 84.5 & 15.0 \\
\hline Nativity: & 4.7 & & & & & \\
\hline Born in US state or territory & & 75.8 & 3.1 & 26.8 & 36.5 & 91.7 \\
\hline Foreign-born & & 24.2 & 96.9 & 73.2 & 63.5 & 8.3 \\
\hline Language of survey: & 0.0 & & & & & \\
\hline English & & 100.0 & 100.0 & 22.1 & 35.4 & 99.5 \\
\hline Spanish & & 0.0 & 0.0 & 77.9 & 64.6 & 0.5 \\
\hline Class position: & 8.6 & & & & & \\
\hline Own or run business & & 5.2 & 5.2 & 6.8 & 9.4 & 6.4 \\
\hline Self-employed/freelance & & 6.4 & 6.2 & 16.1 & 15.6 & 2.5 \\
\hline Supervisory employee & & 35.5 & 27.1 & 20.0 & 27.1 & 31.0 \\
\hline Non-supervisory employee & & 52.9 & 47.9 & 57.1 & 47.9 & 60.1 \\
\hline $\begin{array}{l}\text { Hourly wage, as \% of living wage } \\
\text { (LW): }\end{array}$ & 9.1 & & & & & \\
\hline$\$ 6.00-\$ 10.54 / \mathrm{h}(\leqslant 100 \%$ LW $)$ & & 74.2 & 75.8 & 67.3 & 78.2 & 39.8 \\
\hline$\$ 10.55-\$ 13.16 / \mathrm{h}(>100,<125 \%$ & & 11.9 & 10.5 & 21.6 & 12.9 & 15.9 \\
\hline LW) & & & & & & \\
\hline$\$ 13.17-\$ 15.80 / \mathrm{h}(125-149 \% \mathrm{LW})$ & & 6.6 & 6.3 & 6.7 & 5.0 & 12.4 \\
\hline$\geqslant \$ 15.81 / \mathrm{h}(\geqslant 150 \% \mathrm{LW})$ & & 7.3 & 7.4 & 4.3 & 3.9 & 31.8 \\
\hline Poverty level (household): & 14.5 & & & & & \\
\hline$<100 \%$ poverty & & 59.0 & 57.6 & 61.8 & 61.1 & 29.6 \\
\hline $100-199 \%$ poverty & & 16.7 & 14.1 & 22.5 & 22.1 & 29.6 \\
\hline$\geqslant 200 \%$ poverty & & 24.3 & 28.3 & 15.7 & 16.8 & 40.7 \\
\hline Education: highest level completed: & 9.7 & & & & & \\
\hline$<12$ th grade & & 19.6 & 18.4 & 48.0 & 50.5 & 17.4 \\
\hline High school degree/GED & & 47.7 & 53.1 & 28.2 & 28.9 & 41.3 \\
\hline Some college/vocational school & & 24.8 & 21.4 & 15.8 & 14.4 & 26.9 \\
\hline 4 years of college & & 3.9 & 2.0 & 6.9 & 5.2 & 10.4 \\
\hline Graduate degree & & 3.9 & 5.1 & 1.0 & 1.0 & 4.0 \\
\hline Social desirability score: mean (SD) & 4.7 & $47.4(34.0)$ & $50.5(34.2)$ & $35.7(31.4)$ & $33.2(31.1)$ & $33.2(31.6)$ \\
\hline
\end{tabular}


Table 2

Experiences of Discrimination measure (EOD), plus filing of formal complaint about racial discrimination at work: United for Health cohort $(n=616)$, Greater Boston area, MA, 2004

\begin{tabular}{|c|c|c|c|}
\hline Characteristic & Black $(\%)(n=156)^{\mathrm{a}}$ & Latino $(\%)(n=299)^{\mathrm{a}}$ & White $(\%)(n=205)^{\mathrm{a}}$ \\
\hline Experience of Discrimination $(n=590)$ : & $N=156$ & $n=299$ & $n=205$ \\
\hline \multicolumn{4}{|l|}{ At school: } \\
\hline Never & 79.5 & 91.3 & 90.2 \\
\hline Once & 3.8 & 3.5 & 2.9 \\
\hline $2-3$ times & 7.7 & 3.1 & 2.9 \\
\hline 4 or more times & 9.0 & 2.2 & 3.9 \\
\hline \multicolumn{4}{|l|}{ Getting hired or getting at job: } \\
\hline Never & 72.4 & 80.4 & 85.8 \\
\hline Once & 10.9 & 7.9 & 5.8 \\
\hline $2-3$ times & 9.6 & 6.1 & 5.8 \\
\hline 4 or more times & 7.0 & 5.7 & 2.4 \\
\hline \multicolumn{4}{|l|}{ At work: } \\
\hline Never & 80.8 & 85.6 & 88.3 \\
\hline Once & 6.4 & 6.1 & 2.9 \\
\hline $2-3$ times & 6.4 & 5.2 & 5.8 \\
\hline 4 or more times & 6.4 & 3.1 & 2.9 \\
\hline \multicolumn{4}{|l|}{ Getting housing: } \\
\hline Never & 74.4 & 89.5 & 89.8 \\
\hline Once & 10.9 & 4.8 & 4.9 \\
\hline $2-3$ times & 10.9 & 5.2 & 3.9 \\
\hline 4 or more times & 3.8 & 0.4 & 1.5 \\
\hline \multicolumn{4}{|l|}{ Getting medical care: } \\
\hline Never & 82.7 & 86.0 & 94.2 \\
\hline Once & 8.3 & 8.3 & 1.5 \\
\hline $2-3$ times & 4.5 & 3.5 & 2.4 \\
\hline 4 or more times & 4.5 & 2.2 & 2.0 \\
\hline \multicolumn{4}{|l|}{ Getting services in a store or restaurant: } \\
\hline Never & 59.0 & 80.4 & 89.8 \\
\hline Once & 11.5 & 7.9 & 3.4 \\
\hline $2-3$ times & 14.1 & 8.3 & 3.9 \\
\hline 4 or more times & 15.4 & 3.5 & 2.9 \\
\hline \multicolumn{4}{|l|}{ Getting credit, bank loans, or a mortgage: } \\
\hline Never & 74.4 & 83.8 & 92.2 \\
\hline Once & 9.0 & 7.4 & 2.0 \\
\hline $2-3$ times & 10.3 & 5.7 & 4.9 \\
\hline 4 or more times & 6.4 & 3.1 & 1.0 \\
\hline \multicolumn{4}{|l|}{ On the street or in a public setting: } \\
\hline Never & 68.0 & 76.0 & 84.9 \\
\hline Once & 5.1 & 8.7 & 2.0 \\
\hline $2-3$ times & 17.3 & 10.5 & 6.3 \\
\hline 4 or more times & 9.6 & 4.8 & 6.8 \\
\hline \multicolumn{4}{|l|}{ From the police or in the courts: } \\
\hline Never & 78.2 & 82.5 & 93.7 \\
\hline Once & 6.4 & 7.9 & 2.4 \\
\hline $2-3$ times & 6.4 & 6.6 & 1.5 \\
\hline 4 or more times & 9.0 & 3.1 & 2.4 \\
\hline
\end{tabular}


Table 2 (continued)

\begin{tabular}{|c|c|c|c|}
\hline Characteristic & Black $(\%)(n=156)^{\mathrm{a}}$ & Latino $(\%)(n=299)^{\mathrm{a}}$ & White $(\%)(n=205)^{\mathrm{a}}$ \\
\hline Experience of Discrimination $(n=590)$ : & $N=156$ & $n=299$ & $n=205$ \\
\hline \multicolumn{4}{|l|}{ Situations mentioned: EOD, 9-item } \\
\hline 0 & 33.3 & 52.8 & 58.5 \\
\hline $1-2$ & 28.8 & 23.1 & 29.3 \\
\hline $3+$ & 37.8 & 24.0 & 12.2 \\
\hline \multicolumn{4}{|l|}{ Situations mentioned: EOD, 7-item } \\
\hline 0 & 41.0 & 55.9 & 60.5 \\
\hline $1-2$ & 31.4 & 26.2 & 31.2 \\
\hline $3+$ & 27.6 & 17.9 & 8.3 \\
\hline \multicolumn{4}{|l|}{ Summary score: EOD, 9-item: mean (SD) } \\
\hline Situation (possible range: $0-9$ ) & $2.31(2.46)$ & $1.44(2.06)$ & $0.91(1.62)$ \\
\hline Frequency (possible range: $0-45$ ) & $6.46(8.92)$ & $3.37(5.72)$ & $2.51(4.94)$ \\
\hline \multicolumn{4}{|l|}{ Summary score: EOD, 7-item: mean (SD) } \\
\hline Situation (possible range: $0-7$ ) & $1.64(1.91)$ & $1.09(1.59)$ & $0.73(1.28)$ \\
\hline Frequency (possible range: $0-35$ ) & $4.56(6.80)$ & $2.54(4.31)$ & $2.04(4.01)$ \\
\hline \multicolumn{4}{|l|}{ Cronbach's alpha: } \\
\hline EOD, 9-item, situation & 0.81 & 0.81 & 0.77 \\
\hline EOD, 9 item, frequency & 0.86 & 0.79 & 0.74 \\
\hline EOD, 7-item, situation & 0.87 & 0.75 & 0.70 \\
\hline EOD, 7-item, frequency & 0.82 & 0.71 & 0.67 \\
\hline Response to unfair treatment: & SD & SD & SD \\
\hline Summary score: mean (SD) & $1.32(0.77)$ & $1.13(0.77)$ & $1.25(0.76)$ \\
\hline Cronbach's alpha & 0.56 & 0.37 & 0.49 \\
\hline $\begin{array}{l}\text { Filed a formal complaint about racial } \\
\text { discrimination: } \% \text { yes }\end{array}$ & $7.0 \%$ & $8.7 \%$ & $6.3 \%$ \\
\hline
\end{tabular}

${ }^{\mathrm{a}}$ Based on participants with no missing data.

\section{Test-re-test reliability}

Table 4 presents data on test-re-test reliability for African American and Latino participants combined, since results were similar for both groups. Reliability was high (correlations of 0.69 and higher) for the EOD scores, but much lower for the single-item "worry," "global," and filing a formal complaint questions.

\section{Multi-variable analyses}

The correlation matrix for the different discrimination measures in the validation study is provided in Table 5. Statistically significant correlations in excess of 0.55 occurred between the EOD and Williams Major and Everyday measures; correlations between 0.30 and 0.54 occurred between both the "worry" and "global" questions and the EOD and Everyday measure; and correlations between 0.20 and 0.40 occurred between filing a formal complaint and all of the discrimination measures except for the "global" questions. Social desirability was not correlated with any of the dis- crimination measures except for the Everyday measure $(r=-0.246 ; p=0.0014)$.

The validation SEM was designed to determine whether the various discrimination measures in the matrix tapped into a single construct of self-reported racial discrimination. The resulting model, controlling for social desirability, is shown in Fig. 3. The proposed single-construct model provided an excellent fit to the data $(C F I=0.966$; RMSEA $=0.069)$. The EOD scale, which includes minor and major situations, had the largest correlation with the underlying discrimination construct $(r=0.79)$, followed by the two Williams scales and the global frequency item. Correlations for the less reliable "worry" and "filing a complaint" items were smaller. Social desirability effects were in the expected direction (those with higher desirability levels reported less discrimination); this was due largely to the influence of the Everyday scale.

Additional tests of validity

Data from the key informants $(n=106)$ were obtained for $51 \%$ of the validation study participants, 


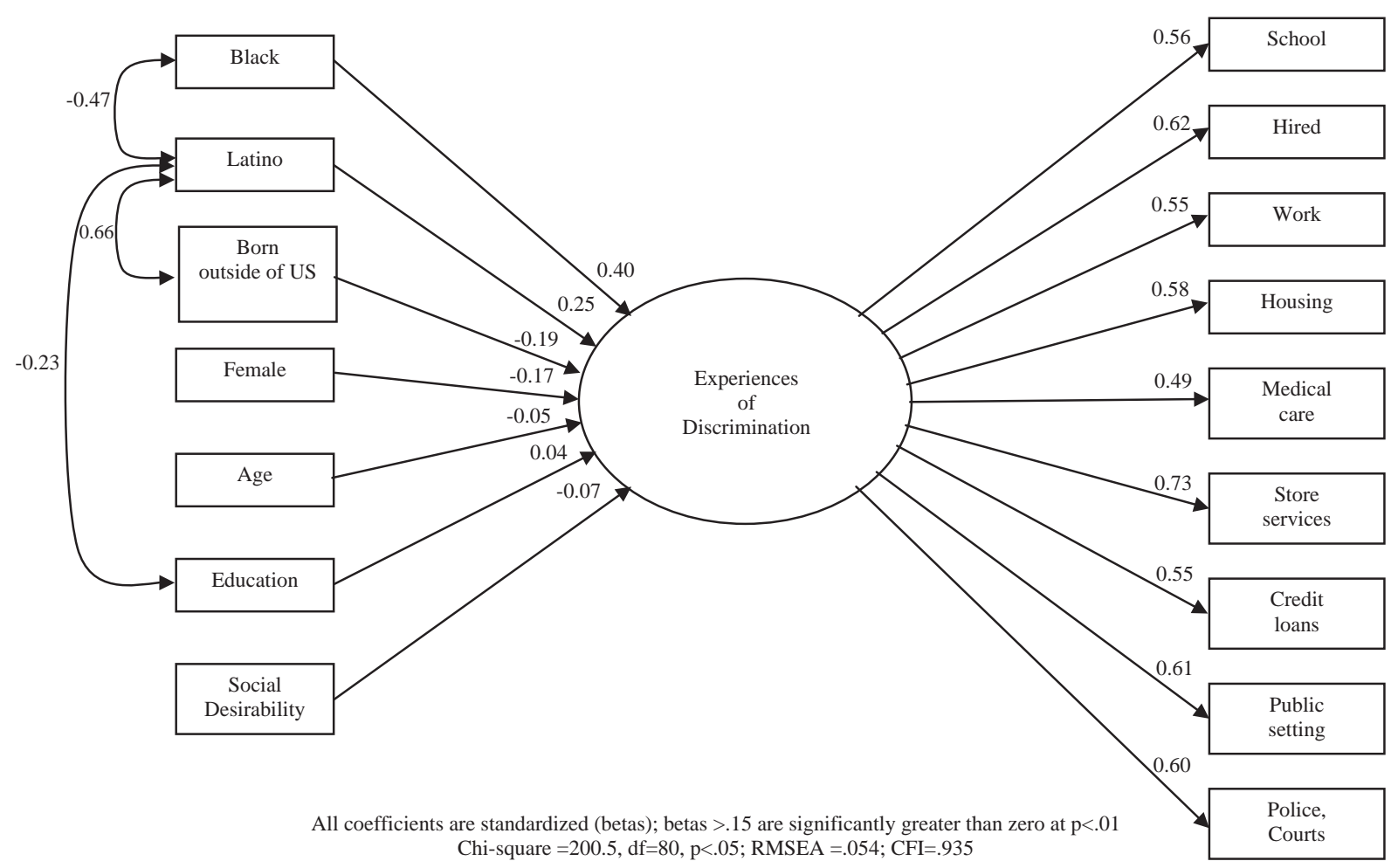

Fig. 2. Experiences of Discrimination (EOD) differential item functioning model, main study $(n=521)$, United for Health, Greater Boston area, MA, 2004.

$75 \%$ of whom had known the participant for at least 5 years. Concordance between the key informants and participants on whether the participants had ever experienced racial discrimination was $68 \% \quad(\kappa$ statistic $=0.35,95 \% \mathrm{CI}=0.18,0.52$ ).

Lastly, Table 6 presents data for the main survey participants on associations between the EOD and the two health outcomes. A positive association with psychological distress was statistically significant in all racial/ethnic groups; the positive association with likelihood of having ever smoked cigarettes tended towards statistical significance for the blacks and Latinos, but not whites.

\section{Discussion}

Our study is among the first to evaluate the psychometric properties of a self-report measure of racial discrimination specifically among working class African American, Latino, and white adults for public health research. The results provide evidence that the 9item EOD scale, whether scored by frequency of occurrence or by situation counts, is a valid and reliable self-report measure of racial discrimination. The confirmatory factor analysis indicated that the EOD items comprised a unidimensional measure of discrimination, with adequate internal consistency and test-re-test reliability; responses were neither associated with social responsibility nor affected by DIF. In our validation analysis, the EOD scale had a higher correlation $(r=0.79)$ with an underlying latent discrimination factor than other indicators. It was also significantly associated with psychological stress, and tended towards being significantly associated with smoking status. The 7-item CARDIA version had similar psychometric properties. Single-item discrimination measures were notably less reliable.

Lending credence to these results, the study response rate was high and, to minimize effects of low literacy and interviewer-interviewee dynamics, we employed ACASI methodology for interview administration, in its first use in research on racial discrimination and health. Moreover, the reported levels of racial discrimination, including higher levels for African Americans compared to Latinos, are similar to those observed in studies using the same or similar measures among working class, less educated, and lower income African Americans and 
Latinos (Yen et al., 1999; Stancil et al., 2000; Stuber et al., 2003; Kessler et al., 1999). Additionally, the multiitem EOD and Williams' measures had much greater

Table 3

Prevalence of self-reported racial discrimination and response to unfair treatment, validation sub-study measures, African Americans $(n=98)$ and Latinos $(n=110)$, United for Health, Greater Boston area, MA, 2004

\begin{tabular}{|c|c|c|}
\hline Characteristic & $\begin{array}{l}\text { African } \\
\text { American }^{a}(\%)\end{array}$ & Latino $^{\mathrm{a}}(\%)$ \\
\hline $\begin{array}{l}\text { Experience of discrimination } \\
(n=207)\end{array}$ & $n=98$ & $n=109$ \\
\hline \multicolumn{3}{|l|}{ Situations mentioned: 9-item } \\
\hline 0 & 27.6 & 43.1 \\
\hline $1-2$ & 26.5 & 30.3 \\
\hline $3+$ & 45.9 & 26.6 \\
\hline \multicolumn{3}{|l|}{ Situations mentioned: 7-item } \\
\hline 0 & 32.6 & 45.9 \\
\hline $1-2$ & 31.6 & 32.1 \\
\hline $3+$ & 35.7 & 22.0 \\
\hline \multicolumn{3}{|c|}{ Summary score: 9-item, mean (SD) } \\
\hline Situation & $2.76(2.62)$ & $1.72(2.24)$ \\
\hline Frequency & $6.55(7.50)$ & $3.63(5.84)$ \\
\hline \multicolumn{3}{|c|}{ Summary score: 7-item, mean (SD) } \\
\hline Situation & $1.98(2.10)$ & $1.36(1.82)$ \\
\hline Frequency & $4.68(6.08)$ & $2.91(4.75)$ \\
\hline \multicolumn{3}{|l|}{ Cronbach's alpha } \\
\hline EOD, 9-item, situation & 0.82 & 0.82 \\
\hline EOD, 9-item, frequency & 0.82 & 0.83 \\
\hline EOD, 7-item, situation & 0.79 & 0.79 \\
\hline EOD, 7-item, frequency & 0.80 & 0.78 \\
\hline
\end{tabular}

Worry about unfair treatment $n=98 \quad n=107$ due to race $(n=205)$

\begin{tabular}{lcr}
\multicolumn{3}{c}{ Worried as a child or teenager about own group } \\
Most of the time & 25.5 & 10.4 \\
Some of the time & 35.7 & 40.6 \\
Rarely or never & 38.8 & 49.1 \\
& & \\
Worried as child or teenager about self & \\
Most of the time & 18.6 & 11.3 \\
Some of the time & 35.0 & 37.7 \\
Rarely or never & 46.4 & 50.9 \\
Worried in last year about own group & \\
Most of the time & 17.4 & 11.2 \\
Some of the time & 39.8 & 36.4 \\
Rarely or never & 42.9 & 52.3 \\
& & \\
Worried in last year about self & \\
Most of the time & 11.3 & 8.4 \\
Some of the time & 34.0 & 34.6 \\
Rarely or never & 54.6 &
\end{tabular}

Table 3 (continued)

\begin{tabular}{lll}
\hline Characteristic & $\begin{array}{l}\text { African } \\
\text { American }^{\mathrm{a}}(\%)\end{array}$ & Latino $^{\mathrm{a}}(\%)$ \\
\hline $\begin{array}{l}\text { Global: racial discrimination } \\
(n=204)\end{array}$ & $n=97$ & $n=107$ \\
\hline
\end{tabular}

How often feel that racial/ethnic groups who are not white, such as African Americans and Latinos, are discriminated against

$\begin{array}{lrr}\text { Never } & 16.5 & 20.6 \\ \text { Rarely } & 9.3 & 13.1 \\ \text { Sometimes } & 37.1 & 44.9 \\ \text { Often } & 37.1 & 21.5\end{array}$

How often feel personally discriminated against

\begin{tabular}{lrr} 
Never & 18.6 & 35.5 \\
Rarely & 30.9 & 24.3 \\
Sometimes & 34.0 & 30.8 \\
Often & 16.5 & 9.4 \\
\hline
\end{tabular}

Filed a formal complaint $\quad n=97 \quad n=107$ $(n=204)$

\begin{tabular}{lcc}
\hline \multicolumn{3}{c}{ Filed formal complaint about racial discrimination } \\
Yes & 12.4 & 5.6 \\
\hline Willams: Major & $n=95$ & $n=105$ \\
discrimination $(n=200)$ & & \\
\hline Situations mentioned with racial reason for discrimination \\
0 & 48.2 & 69.5 \\
$1-2$ & 33.7 & 25.7 \\
$3+$ & 17.9 & 4.8 \\
Summary score: mean (SD) & $1.20(1.68)$ & $0.50(0.93)$ \\
Cronbach's alpha & 0.71 & 0.52 \\
\hline Williams: Everyday & $n=85$ & $n=87$ \\
discrimination $(n=172)$ & & \\
\hline
\end{tabular}

Main reason for these experiences (asked if person replied "yes" to at least one query)
Racial
69.4
40.2
Other or unstated reason 30.6
59.8

Situations mentioned with racial reason for discrimination

$\begin{array}{lcc}0 & 11.8 & 18.4 \\ 1-2 & 5.9 & 19.5 \\ 3+ & 82.4 & 62.1 \\ \text { Summary score: mean (SD) } & 6.35(3.26) & 4.41(3.39) \\ \text { Cronbach's alpha } & 0.88 & 0.88\end{array}$

\footnotetext{
${ }^{\mathrm{a}}$ Based on participants with no missing data, as indicated for each question.
}

reliability than the single-item questions, findings which raise questions about the use of single-item measures in prior research and caution against their use in future 
Table 4

Test-re-test reliability, for measures of racial discrimination and response to unfair treatment $(n=190 ; 94$ African Americans, 96 Latinos), "United for Health," Greater Boston area, MA, 2004

\begin{tabular}{|c|c|c|c|}
\hline \multirow[t]{3}{*}{ Measure continuous } & \multicolumn{3}{|c|}{ Total $(n=190)$} \\
\hline & \multicolumn{2}{|c|}{ Score: mean (SD) } & \multirow[t]{2}{*}{ Correlation $(95 \% \mathrm{CI})$} \\
\hline & Initial & Re-test & \\
\hline EOD: Frequency, 9-item & $5.66(8.12)$ & $5.30(6.99)$ & $0.70(0.61,0.76)$ \\
\hline EOD: Situation, 9-item & $2.04(2.36)$ & $2.30(2.53)$ & $0.69(0.61,0.76)$ \\
\hline EOD: Frequency, 7-item & $3.98(6.03)$ & $3.99(5.64)$ & $0.72(0.64,0.78)$ \\
\hline EOD: Situation, 7-item & $1.46(1.81)$ & $1.74(2.02)$ & $0.69(0.61,0.76)$ \\
\hline EOD: Response to unfair treatment & $1.25(0.79)$ & $1.41(0.78)$ & $0.35(0.22,0.47)$ \\
\hline Worry: Own group & $2.36(0.70)$ & $2.32(0.72)$ & $0.30(0.17,0.43)$ \\
\hline Worry: Self & $2.41(0.74)$ & $2.44(0.68)$ & $0.42(0.30,0.53)$ \\
\hline Global: Group & $2.72(1.03)$ & $2.84(1.06)$ & $0.46(0.34,0.56)$ \\
\hline Global: Self & $2.20(1.05)$ & $2.34(1.02)$ & $0.50(0.38,0.60)$ \\
\hline \multicolumn{4}{|l|}{ Categorical } \\
\hline & Initial $(\%)$ & Re-test (\%) & Kappa $(95 \%$ CI $)$ \\
\hline Filed complaint & 8.4 & 8.4 & $0.18(-0.03,0.39)$ \\
\hline \multicolumn{4}{|l|}{ EOD: Response to unfair treatment } \\
\hline$\%$ Act & 56.3 & 66.3 & $0.33(0.20,0.46)$ \\
\hline$\%$ Accept & 43.7 & 33.7 & \\
\hline$\%$ Talk & 68.4 & 74.7 & $0.30(0.16,0.45)$ \\
\hline$\%$ Quiet & 31.6 & 25.3 & \\
\hline
\end{tabular}

studies. Further suggesting the single-item self-report data on filing a formal complaint are unreliable, national data indicate that black Americans are 55 times more likely than white Americans to file complaints about racial discrimination at work (Pincus, 2003, p. 109) and new empirical research indicates that claims of workplace discrimination by white Americans are more likely to be ideological rather than evidence-based (Bonilla-Silva, 2003; Pincus, 2003; Crosby, 2004).

Despite its promising psychometric properties, the EOD, like any other self-report measure, necessarily is subject to the same social and cognitive limitations as other self-report measures, regarding perception, interpretation, and disclosure (Stone et al., 2000; Blank et al., 2004; Krieger, 2003). The deliberate focus on a working class population, in which people of color are disproportionately represented (Smith, 2001), necessarily limited ability to compare results by socioeconomic position. Additional research is needed to determine whether our findings can be generalized to US black and Latino professionals, to different Latino sub-populations (e.g., Mexican, Puerto Rican, Cuban, other Central and South American) and to other racial/ethnic groups, and whether differences exist by nativity and immigration history. Underscoring the need for this research, to date US studies on racial discrimination and health have generally ignored differences regarding socioeconomic position and nativity among the US black population (Krieger, 2000; Williams et al., 2003; Poston et al., 2001).

Data on associations between the discrimination measures and the health outcomes were intended only as a gauge of validity, not detailed analysis. Nevertheless, the magnitude and direction of the crude correlations are comparable to those reported in recent studies regarding: (a) psychological distress among US black and Latino adults (Stuber et al., 2003; Kessler et al., 1999; Williams et al., 1997; Finch, Kolody, \& Vega, 2000), and (b) cigarette smoking among US black adults and African American girls (Landrine \& Klonoff, 2000; Guthrie et al., 2002); no previous analyses have reported on this association for Latinos. Once data collection for the full United for Health cohort is complete, future analyses will systematically investigate the relationship between self-reported experiences of racial discrimination with these and other health outcomes, taking into account necessary confounders and other covariates; speculation on the reasons for the crude correlations reported in this study is premature.

Utilizing valid self-report measures of exposure, however vital, nevertheless addresses only one aspect of the myriad complexities affecting analyses of how racism harms health, via diverse pathways involving 
Table 5

Correlation matrix of the racial discrimination instruments: Experience of Discrimination (EOD), worry, global, and Williams', plus social desirability scale, for all participants ( $n=165 ; 84$ African Americans, 81 Latinos) with no missing data for any of these items in the validation sub-study, United for Health, Greater Boston area, MA, 2004

Measure of

All participants with no missing data for any item in matrix $(n=165)$

discrimination

Pearson correlation coefficien

( $p$-value)

\begin{tabular}{|c|c|c|c|c|c|c|c|c|c|}
\hline \multicolumn{2}{|c|}{$\begin{array}{l}\text { Experience of } \\
\text { Discrimination (EOD): } \\
\text { score ( } 9 \text { variable version) }\end{array}$} & \multicolumn{2}{|c|}{ Worry during past year for } & \multicolumn{2}{|c|}{ Global measure, for } & \multicolumn{2}{|c|}{ Williams } & \multirow[t]{2}{*}{$\begin{array}{l}\text { Social } \\
\text { desirability }\end{array}$} & \multirow[t]{2}{*}{$\begin{array}{l}\text { Filed } \\
\text { complaint }\end{array}$} \\
\hline Frequency & Situation & Own group & Self & $\begin{array}{l}\text { Racial/ethnic } \\
\text { groups }\end{array}$ & Self & Major & Everyday & & \\
\hline
\end{tabular}

EOD:

Frequency, 9 variable

EOD:

Situation, 9 variable

Worry: own group

Worry: self

Global: group

Global: self

Williams: major

Williams: everyday

$0.900 \quad 1$

$(p<0.0001)$

$\begin{array}{lll}0.423 & 0.412 \quad 1\end{array}$

$(p<0.0001) \quad(p<0.0001)$

$\begin{array}{llll}0.411 & 0.376 & 0.640 & 1\end{array}$

$\begin{array}{lll}(p<0.0001) & (p<0.0001) \quad(p<0.0001)\end{array}$

$0.412 \quad 0.404 \quad 0.338$

$\begin{array}{llll}(p<0.0001) & (p<0.0001) & (p<0.0001) & 0.380\end{array}$

$\quad(p<0.0001)$

$\begin{array}{lllll}0557 & 0.531 & 0.416 & 0.403 & 0.498\end{array}$

$\begin{array}{lllll}(p<0.0001) & (p<0.0001) & (p<0.0001) & (p<0.0001) & (p<0.0001)\end{array}$

$\begin{array}{llll}(p<0.0001) & (p<0.0001) & (p<0.0001) & (p=0.0016) \quad(p=0.0280)\end{array}$

$0.564-0.612$

$\begin{array}{lllll}p<0.0001) & (p<0.0001) & (p<0.0001) & (p<0.0001) & (p<0.0001)\end{array}$

$\begin{array}{lllll}-0.065 & -0.048 & 0.060 & 0.027 & 0.005\end{array}$

$\begin{array}{lllll}(p=0.4097) & (p=0.542) & (p=0.4462) & (p=0.734) & (p=0.9500)\end{array}$

0.274

0.387

0.200

$0.145 \quad 0.091$

$(p=0.2456)$

0.335

$(p<0.0001)$

$0.528 \quad 0.463$

0.463
$p<0.0001)$

$(p<0.0001) \quad(p<0.0001)$

$\begin{array}{lll}-0.008 & -0.108 & -0.246\end{array}$

$-0.246$

$(p=0.0004) \quad(p<0.0001) \quad(p=0.0101) \quad(p=0.625)$
0.201
0.333
0.194

$(p=0.0096)$

$(p<0.0001)$

$(p=0.3874)$

$-0.068$

$(p=0.0123)$ 


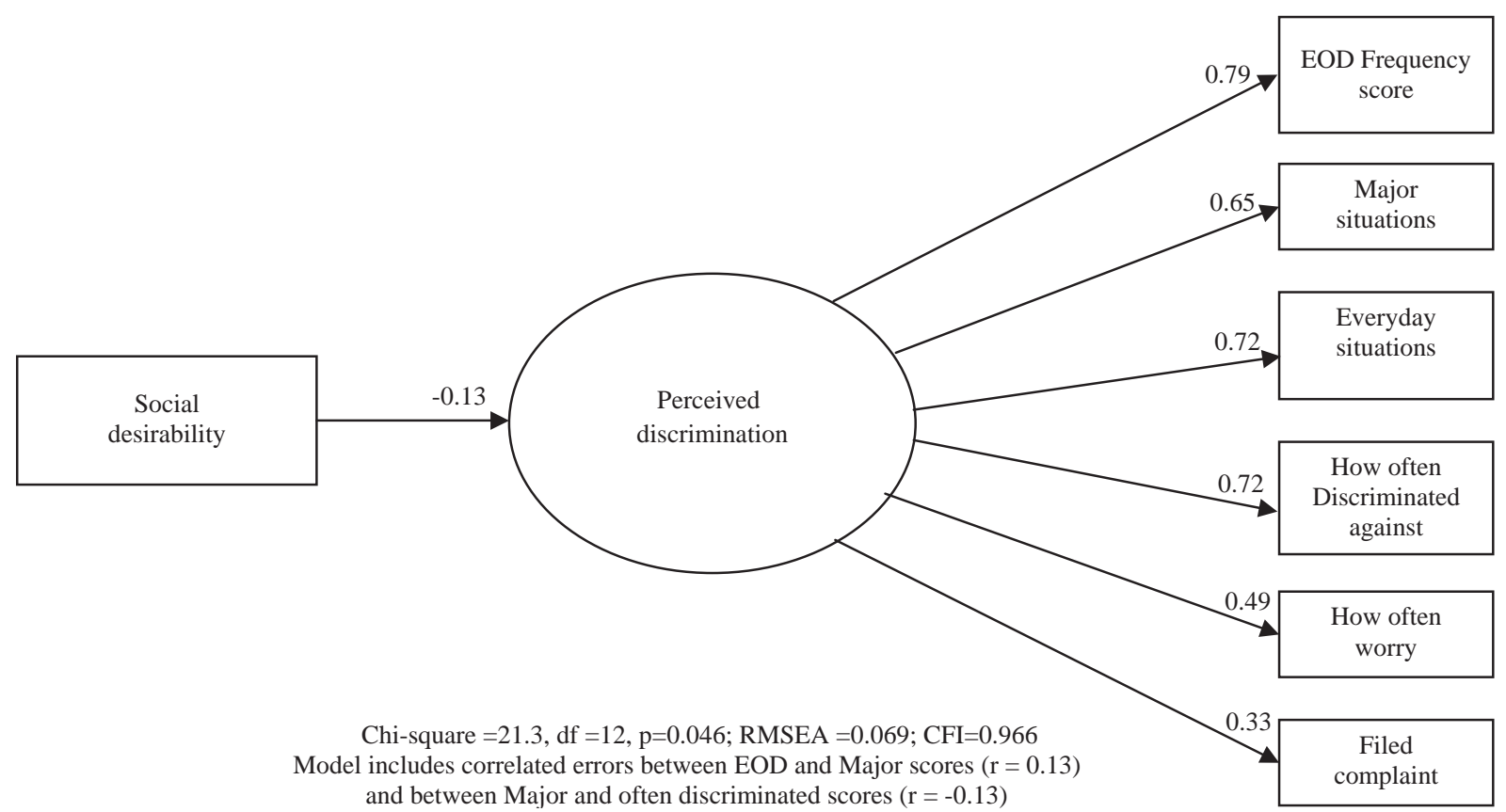

Fig. 3. Construct validity model for multiple measures of racial discrimination, validation sub-study $(n=165)$, United for Health, Greater Boston area, MA, 2004.

structural, institutional, interpersonal, and internalized racism (Krieger, 2000, 2003; Williams et al., 2003; Blank et al., 2004). For observational studies, challenges include: (a) confounding by other socially patterned covariates, and (b) aptly measuring relevant variables in relation to the relevant etiologic period and chronicity and level of exposure (Krieger, 2000, 2001, 2003; Krieger \& Davey Smith, 2004; Davey Smith \& Ebrahim, 2002; Williams et al., 2003). For experimental investigations, additional concerns pertain to the feasibility of developing socially and biologically realistic exposure scenarios and relating them to meaningful changes in health status (Blank et al., 2004; Harrell, Hall, \& Taliaferro, 2003).

In conclusion, our study underscores the need for the newly emerging research on how racism harms health to use validated, multi-item self-report measures of experiences of racial discrimination. By testing the validity and reliability of the EOD in a population of working class African American and Latino adults and ascertaining it has promising psychometric properties, our study lends credence to prior investigations using related versions of this instrument while also expanding possibilities for furthering research on-and generating evidence to galvanize action to address-social inequalities in health.

\section{Acknowledgements}

This validation study was supported by the American Legacy Foundation (PI = Krieger) and the parent study in which it was nested, "United for Health," was funded by the National Institute of Occupational Safety and Health (grant \# 1R01 OHO7366-01; PI = Barbeau). Both institutions solely provided funding and had no involvement in: the design or conduct of the study; the collection, management, analysis, or interpretation of the data; or the preparation, review, or approval of the manuscript.

The authors thank, in alphabetical order, the following team members of the "United for Health" study for the work that made our validation sub-study possible: (a) interviewers: Vanessa Costa, Maribel Melendez, Michael Ostler, Elizabeth Pratt, Roona Ray, and Marie Recupero; (b) instrument formatting and data management: Lisa Bates and Ruth Lederman; and (c) additional co-investigators and team members engaged in the overall project: Margaret Quinn, Grace Sembajwe, Glorian Sorensen, Anne Stoddard, Pamela D. Waterman, and Richard Youngstrom.

The authors also thank David Williams for permission to include his instrument and for instructions on how it should be scored. 
Table 6

Distribution of psychological distress and cigarette smoking and association with Experiences of Discrimination (EOD) for main survey participants $(n=616)$, United for Health, Greater Boston area, MA, 2004

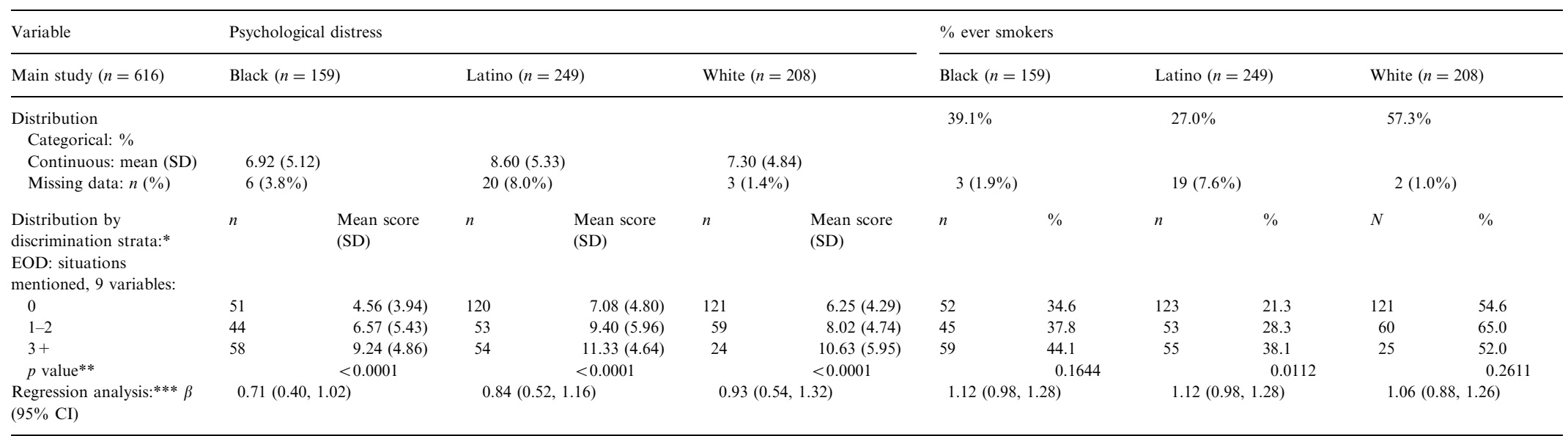

*analyses based on participants with no missing data.** $p$-value: for psychological distress, for the $F$ statistic (ANOVA); for ever smoker, for the Cochran-Armitage test for trend ***Regression analysis: psychological distress = ordinary least squares linear regression; ever smoker $=$ logistic regression. 


\section{Appendix 1}

Experiences of Discrimination, worry, global, and Williams questions on racial discrimination, in English and Spanish.

\begin{tabular}{ll}
\hline Measure & Question (English version) \\
\hline $\begin{array}{l}\text { Experience of } \\
\text { Discrimination (EOD) }\end{array}$ & $\begin{array}{l}\text { Introduction: "This next section is going to ask } \\
\text { about how you and others like you are treated, } \\
\text { and how you typically respond" }\end{array}$ \\
$\begin{array}{l}\text { Response to unfair } \\
\text { treatmentf }\end{array}$ & $\begin{array}{l}\text { If you feel you have been treated unfairly, do you } \\
\text { usually: (please select the best response) }\end{array}$ \\
& $\begin{array}{l}\text { If you have been treated unfairly, do you usually: } \\
\text { (please select the best response) }\end{array}$
\end{tabular}

Discrimination

\section{Worry questions}

\section{Global questions}

Have you ever experienced discrimination, been prevented from doing something, or been hassled or made to feel inferior in any of the following situations because of your race, ethnicity, or color?

(1) At school?

(2) Getting hired or getting a job?

(3) At work?

(4) Getting housing?

(5) Getting medical care?

(6) Getting service in a store or restaurant?

(7) Getting credit, bank loans, or a mortgage?

(8) On the street or in a public setting?

(9) From the police or in the courts?

(1) When you were a child or teenager (up to age 18), how much did you worry about people in your racial/ethnic group experiencing unfair treatment because of their race, ethnicity, or color?

(2) When you were a child or teenager (up to age 18 ), how much did you worry about your experiencing unfair treatment because of your race, ethnicity, or color?

(3) In the last year, how much did you worry about people in your racial/ethnic group experiencing unfair treatment because of their race, ethnicity, or color?

(4) In the last year, how much did you worry about your experiencing unfair treatment because of your race, ethnicity, or color?

(1) How often do you feel that racial/ethnic groups who are not white, such as African Americans and Latinos, are discriminated against? (choose the number that best represents how you feel)

(2) How often do you feel that you, personally, have been discriminated against because of your race, ethnicity, or color? choose the number that best represents how you feel)

\section{Stem}

1. Accept it as a fact of life

2. Try to do something about it

1. Talk to other people about it

2. Keep it to yourself

For each situation to which the participant replied "yes" (versus "no"), the follow-up question was: How many times did this happen?

1. Once

2. Two or three times

3. Four or more times
The response options for the "worry" questions were:

1. Most of the time

2. Some of the time

3. Rarely or never
Response options were:

1. Never

2. Rarely

3. Sometimes

4. Often 
Filed complaint

Williams questions

Major discrimination

Day-to-day unfair treatment
Have you ever filed a formal complaint because of racial discrimination?

1. Yes

2. No

Introduction: "In the following questions, we are interested in the way other people have treated you or your beliefs about how other people have treated you. Can you tell me if any of the following has ever happened to you:"

(1) At any time in your life, have you ever been unfairly fired?

(2) For unfair reasons, have you ever not been hired for a job?

(3) Have you ever been unfairly denied a promotion?

(4) Have you ever been unfairly stopped, searched, questioned, physically threatened or abused by the police?

(5) Have you ever been unfairly discouraged by a teacher or advisor from continuing your education?

(6) Have you ever been unfairly prevented from moving into a neighborhood because the landlord or a realtor refused to sell or rent you a house or apartment?

(7) Have you ever moved into a neighborhood where neighbors made life difficult for you or your family?

(8) Have you ever been unfairly denied a bank loan?

(9) Have you ever received service from someone such as a plumber or car mechanic that was worse than what other people get?

In your day-to-day life, how often have any of the following things happened to you?

(1) You have been treated with less courtesy than other people

(2) You have been treated with less respect than other people

(3) You have received poorer service than other people at restaurants or stores

(4) People have acted as if they think you are not smart

(5) People have acted as if they are afraid of you

(6) People have acted as if they think you are dishonest

(7) People have acted as if they're better than you are

(8) You have been called names or insulted

(9) You have been threatened or harassed

(10) You have been followed around in stores
For each situation to which the participant replied "yes," the followup question was:

What do you think was the main reason for this experience?

1. Your ancestry or national origins

2. Your gender

3. Your race

4. Your age

5. Your religion

6. Your height or weight

7. Your shade of skin color

8. Your sexual orientation

9. Your education or income level

10. A physical disability

11. Other

Response options were:

1. Four or more times

2. Two or three times

3. Once

4. Never

Respondents who indicated any of these events occurred at least once were then asked one question, covering all the situations:

What do you think was the main reason for this/these experience(s)?

1. Your ancestry or national origins

2. Your gender

3. Your race

4. Your age

5. Your religion

6. Your height or weight

7. Your shade of skin color

8. Your sexual orientation

9. Your education or income level

10. A physical disability

11. Other 


\section{Response to unfair treatment}

\section{Measure \\ Experience of Discrimination (EOD)}

Response to unfair treatment

\section{Discrimination}

\section{Worry questions}

How did you respond to this/these experience(s)? Please tell me if you did each of the following things.

(1) Tried to do something about it

(2) Accepted it as a fact of life

(3) Worked harder to prove them wrong

(4) Realized that you brought it on yourself

(5) Talked to someone about who you were feeling

(6) Expressed anger or got mad

(7) Prayed about the situation

\section{Question (Spanish version)}

Introduction: "En esta sección se le preguntará acerca de cómo usted, y otros como usted, son tratados, y cómo usted responde típicamente" En caso de sentir que ha sido tratado de manera injusta, usted normalmente: (por favor elija la mejor respuesta)

Si usted ha sido tratado injustamente, usted normalmente: (por favor elija la mejor respuesta)

¿Alguna vez ha experimentado discriminación, no se le ha permitido hacer algo, se le ha molestado o hecho sentir inferior en alguna de las siguientes situaciones debido a su raza, etnia o color?

(1) ¿En la escuela?

(2) ¿Al ser contratado u obtener un empleo?

(3) ¿En el trabajo?

(4) ¿Al obtener una casa?

(5) ¿Al obtener asistencia médica?

(6) ¿El requerir servicio en una tienda o restaurante?

(7) ¿Al obtener crédito, préstamos bancarios o hipotecarios?

(8) ¿En la calle, en un lugar público?

(9) ¿De la policía o en las cortes?

(1) Cuando era niño o adolescente (hasta los 18 años), ¿cuánto se preocupó de que gente de su grupo racial/étnico experimentara trato injusto debido a su raza, etnia o color?

(2) Cuando era niño o adolescente (hasta los 18 años), ¿cuánto se preocupó de que usted experimentara trato injusto debido a su raza, etnia o color?

(3) Durante el año pasado, ¿cuánto se preocupó de que gente de su grupo racial/étnico experimentara trato injusto debido a su raza, etnia o color?

(4) Durante el año pasado, ¿cuánto se preocupó de que usted experimentara trato injusto debido a su raza, etnia o color?
Response option for each item:

1. Yes

2. No

Stem

1. lo toma como un hecho de su vida

2. trata de hacer algo al respecto

1. habla acerca de esto con otras personas

2. se lo guarda para sí mismo

For each situation to which the participant replied "Sí' (versus "No"), the follow-up question was:

¿Cuántas veces ocurrió esto?

1. una vez

2. dos o tres veces

3. cuatro o más veces

The response options for the "worry" questions were:

1. Casi todo el tiempo

2. Algunas veces

3. Rara vez o nunca 


\section{Global questions}

Filed complaint

Williams questions

Major discrimination

Day-to-day unfair treatment
(1) ¿Con qué frecuencia siente que grupos raciales/étnicos, quienes no son blancos, como afroamericanos y latinos, son discriminados? (Escoja el número que mejor represente su sentimiento)

(2) ¿Con qué frecuencia siente que usted, personalmente, ha sido discriminados, dada su raza, etnia o color? (Escoja el número que mejor represente su sentimiento)

¿Alguna vez ha presentado una queja formal por causas de discriminación racial?

Introduction: "En las siguientes preguntas, estamos interesados en la manera que otras personas te tratan a ti y tus creencias. Puedes decir si cualquiera de lo siguiente le ha ocurido."

(1) iAlguna vez en su vida, usted ha sido despedido injustamente? En cualquier veces en su vida, usted jamás ha sido despedido injustamente?

(2) ¿Por razones injustas le han sido negado empleo?

(3) ¿Por razones injustas le ha sido negado una promoción?

(4) iAlguna vez has sido parado, registrado fisicamente, interrogado, amenazado o abusado injustamente por la policia?

(5) ¿Ha sido desanimado injustamente por un maestro o consejero de continuar su educacion?

(6) ¿A usted le han inpedido injustamente mudarse a un vencindario porque al propietario o un corredor de bienes raíces nego venderle o alquilarle una casa o apartamento?

(7) ¿Usted se ha mudado a otro vencindario donde los vecinos les han hecho la vida difícil para usted o para su familia?

(8) ¿Le ha sido a usted negado injustamente un préstamo bancario?

(9) ¿Has recibido servicio de alguien como un plomero o mecánico de autos que era peor del que otras personas recibieron?

¿En su vida día a día, cuántas veces le sucedio las siguientes cosas?

(1) Usted ha sido tratado con menos cortesía que a otra gente

(2) Usted ha sido tratado con menos respeto que a otra gente

(3) Usted ha recibido el servicio más bajo que otra gente en restaurantes o tiendas

(4) Personas han actuado como si ellos piensan que usted no es inteligente

(5) Personas han actuado como si ellos tienen miedo de usted
Response options were:

1. Nunca

2. Casi nunca

3. Algunas veces

4. Con frecuencia

1. Sí

2. No

For each situation to which the participant replied "Sí "(versus "No"), the follow-up question was: ¿Cual piensas fue la principal razón por esta experiencia?

1. Tu ascendencia u orígenes nacionales

2. Tu sexo

3. Tu raza

4. Tu edad

5. Tu religión

6. Tu altura o peso

7. Tu color de piel

8. Tu orientación sexual

9. Tu educación o nivel de ingresos

10. Una incapacidad física

11. Otra razón

Response options were:

1. Cuatro o más veces

2. Dos o tres veces

3. Una vez

4. Nunca

Respondents who indicated any of these events occurred at least once were then asked one question, covering all the situations: 
(6) Personas han actuado como si ellos piensan que usted no es honrado

(7) Personas han actuado como si ellos son mejor que usted es

(8) Usted ha sido llamado por apodos o insultad

(9) Usted ha sido amenazado o ha sido acosado

(10) Usted ha sido vigilado en las tiendas
¿Cual piensa fue para usted la razón principal de estas experiencias? ¿Diría usted...?

1. $\mathrm{Tu}$ ascendencia $\mathrm{u}$ orígenes nacionales

2. Tu sexo

3. Tu raza

4. Tu edad

5. Tu religión

6. Tu altura o peso

7. Tu color de piel

8. Tu orientación sexual

9. Tu educación o nivel de ingresos

10. Una incapacidad física

11. Otra razón

Response option for each item:

¿Cómo respondió usted a estas experiences (s)?

Dígame por favor si usted hizo cada una de las siguientes cosas.

(1) Trato de hacer algo

1. Sí

(2) Lo acepto como un hecho de la vida

2. No

(3) Trabajo más duro para probar que estaban

(4) Se dio cuenta que usted lo trajo en usted mismo

(5) Hablo con alguien acerca de cómo usted se sentía

(6) Expreso cólera o se enojo

(7) Oro acerca de la situación

\section{References}

Association of Community Organizations for Reform Now (ACORN), 2004. Living Wage Resource Center. Available at: http://www.livingwagecampaign.org; accessed: July 25.

Banton, M. (1998). Racial theories (2nd ed). Cambridge: Cambridge University Press.

Barbarin, O. A., Good, P. R., Pharr, M., \& Siskind, J. A. (Eds.). (1981). Institutional racism and community competence. Rockville, Md.; Washington, DC: US Dept. of Health and Human Services, Public Health Service, Alcohol, Drug Abuse, and Mental Health Administration, National Institute of Mental Health, Center for Minority Group Mental Health Programs; US Government Printing Office. DHHS publication no. (ADM) 81-907.

Blank, R.M., Dabady, M., Citro, C.F., (Eds.), (2004). Measuring racial discrimination. Panel on Methods for Assessing Discrimination, National Research Council. Washington, DC: The National Academies Press.

Bonilla-Silva, E. (2003). Racism without racists: color-blind racism and the persistence of racial inequality in the United States. Lanham, MD: Rowman \& Littlefield.

Boomsma, A., \& Hoogland, J. J. (2001). The robustness of LISREL modeling revisited. In R. Cudeck, S. du Toit, \& D. Sorbom (Eds.), Structural equation modeling: present and future. Chicago: Scientific Software International.
Byrd, W. M., \& Clayton, L. (2000). An American health dilemma: the medical history of African Americans and the problem of race, Vol. 1. New York: Routledge.

Crosby, F. J. (2004). Affirmative action is dead: long live affirmative action. New Haven: Yale University Press.

Davey Smith, G., \& Ebrahim, S. (2002). Data dredging, bias, or confounding. British Medical Journal, 325, 1437-1438.

Dole, N., Savitz, D. A., Siega-Riz, A. M., Hertz-Picciotto, I., McMahon, M. J., \& Buekens, P. (2004). Psychosocial factors and preterm birth among African American and white women in Central North Carolina. American Journal of Public Health, 94, 1358-1365.

Finch, B. K., Kolody, B., \& Vega, W. A. (2000). Perceived discrimination and depression among Mexican-origin adults in California. Journal of Health and Social Behavior, 41, 295-313.

Fleishman, J. A., \& Lawrence, W. F. (2003). Demographic variation in SF-12 scores: True differences or differential item functioning? Medical Care, 41(Suppl), III-75-III-86.

Guthrie, B. J., Young, A. M., Williams, D. R., Boyd, C. J., \& Kintner, E. K. (2002). African American girls' smoking habits and day-to-day experiences with racial discrimination. Nursing Research, 51, 183-190.

Guyll, M., Matthews, K. A., \& Bromberger, J. T. (2001). Discrimination and unfair treatment: relationship to cardiovascular reactivity among African American and 
European American women. Health Psychology, 20, 315-325.

Harrell, J. P., Hall, S., \& Taliaferro, J. (2003). Physiological responses to racism and discrimination: an assessment of the evidence. American Journal of Public Health, 93, 242-248.

Hays, R. D. \& the RAND Corporation. (1989). A five-item measure of socially desirable response set. Educational Psychology Measurement, 49, 629-636.

Hiett, R. L., McBride, R. S., Fiman, B. G., Thomas, J. A., O'Mara, F. E., \& Sevilla, E. (1978). The racial attitudes and perceptions survey (RAPS) Technical Paper 338. Monterey, CA: US Army Research Institute for the Behavioral and Social Sciences.

Joreskog, K., \& Sorbom, D. (1993). LISREL 8: structural equation modeling with the SIMPLIS Command Language. Hillsdale, NJ: Lawrence Erlbaum Association.

Kessler, R. C., Andrew, G., Colpe, L. J., Hiripi, E., Mroczek, D. K., Normand, S. L. T., Walters, E. E., \& Zaslovsky, A. (2002). Short screening scales to monitor population prevalences and trends in nonspecific psychological distress. Psychological Medicine, 32, 959-976.

Kessler, R. C., Michelson, K. D., \& Williams, D. R. (1999). The prevalence, distribution and mental health correlates of perceived discrimination in the United States. Journal of Health and Social Behavior, 40, 208-230.

Krieger, N. (1990). Racial and gender discrimination: risk factors for high blood pressure? Social Science \& Medicine, 30, 1273-1281.

Krieger, N. (2000). Discrimination and health. In L. Berkman, \& I. Kawachi (Eds.), Social epidemiology (pp. 36-75). New York: Oxford University Press.

Krieger, N. (2001). Theories for social epidemiology in the 21st century: An ecosocial perspective. International Journal of Epidemiology, 30, 668-677.

Krieger, N. (2003). Does racism harm health? Did child abuse exist before 1962? On explicit questions, critical science, and current controversies: An ecosocial perspective. American Journal of Public Health, 93, 194-199.

Krieger, N., Rowley, D., Herman, A. A., Avery, B., \& Phillips, M. T. (1993). Racism, sexism, and social class: Implications for studies of health, disease, and well-being. American Journal of Preventive Medicine, 6(Suppl), 82-122.

Krieger, N., \& Sidney, S. (1996). Racial discrimination and blood pressure: the CARDIA study of young black and white adults. American Journal of Public Health, 86, 1370-1378.

Landrine, H., \& Klonoff, E. A. (2000). Racial discrimination and cigarette smoking among Blacks: Findings from two studies. Ethnicity \& Disease, 10, 195-202.

MacCallum, R. C., Widaman, K. F., Preacher, K. J., \& Hong, S. (2001). Sample size in factor analysis: The role of model error. Multivariate Behavioral Research, 36, 611-637.

McNeilly, M. D., Anderson, N. B., Armstead, C. A., Clark, R., Corbett, M., Robinson, E. L., Pieper, C. F., \& Lepisto, E. M. (1996). The perceived racism scale: A multidimensional assessment of the experience of white racism among African Americans. Ethnicity \& Disease, 6, 156-166.

Office of Applied Studies, Substance Abuse and Mental Health Services Administration, US Department of Health and Human Services, (2001). Development of computer-assisted interviewing procedures for the national household survey on drug abuse. Available at: http://www.oas.samhsa.gov/ nhsda/CompAssistInterview/toc.htm\#TopOfPage. Accessed on: July 29, 2004.

Pincus, F. L. (2003). Reverse discrimination: Dismantling the myth. Boulder, CO: Lynne Rienner.

Poston, W. S., Pavlik, V. N., Hyman, D. J., Ogbonnaya, K., Hanis, C. L., Haddock, C. K., Hyder, M. L., \& Foreyt, J. P. (2001). Genetic bottlenecks, perceived racism, and hypertension risk among African Americans and first-generation African immigrants. Journal of Human Hypertension, 15, 341-351.

SAS Institute, Inc. (2001). SAS Language Reference, Version 8. Cary, NC: SAS Institute.

Smedley, B. D., Stith, A. Y., \& Nelson, A. R. (Eds.). (2003). Unequal treatment: Confronting racial and ethnic disparities in health care. Committee on Understanding and Eliminating Racial and Ethnic Disparities in Health Care, Board on Health Sciences Policy, Institute of Medicine. Washington, DC: National Academy Press.

Smith, J. P. (2001). Race and ethnicity in the labor market: trends over the short and long term. In N. J. Smelser, W. J. Wilson, \& F. Mitchell (Eds.), American becoming: Racial trends and their consequences, Vol. II (pp. 52-97). Commission on Behavioral and Social Sciences and Education, National Research Council. Washington, DC: National Academy Press.

Stancil, T. R., Hertz-Picciotto, I., Schramm, M., \& WattMorse, M. (2000). Stress and pregnancy among African-American women. Paediatric and Perinatal Epidemiology, 14, $127-135$.

Stone, A. A., Turkann, J. S., Bachrach, C. A., Jobe, J. B., Kurtzmann, H. S., \& Cain, V. S. (Eds.). (2000). The science of self-report: Implications for research and practice. Mahwah, NJ: Lawrence Erlbaum Associates.

Stuber, J., Galea, S., Ahern, J., Blaney, S., \& Fuller, C. (2003). The association between multiple domains of discrimination and self-assessed health: A multilevel analysis of Latinos and blacks in four low-income New York City neighborhoods. Health Service Research, 38(6 Part 2), 1735-1759.

Trosclair, A., Husten, C., Pederson, L., \& Dhillon, I. (2002). Centers for disease control and prevention: Cigarette smoking among adults-United States, 2000. MMWR Morbidity and Mortality Weekly Report, 51, 642-645.

US Census Bureau, 2004. Poverty thresholds, 2003. Available at: http://www.census.gov/hhes/poverty/threshld/thresh03. html. Accessed: July 4.

Utsey, S. O. (1998). Assessing the stressful effects of racism: A review of instrumentation. Journal of Black Psychology, 24, 269-288.

Vines, A. I., McNeilly, M. D., Stevens, J., Hertz-Picciotto, I., Baird, M., \& Baird, D. D. (2001). Development and reliability of a telephone-administered perceived racism scale (TPRS): A tool for epidemiological use. Ethnicity \& Disease, 11, 251-262.

Waters, M. C. (1999). Black identities: West Indian immigrant dreams and American realities. Cambridge, MA: Harvard University Press.

Williams, D. R., \& Jackson, J. S. (2000). Race/ethnicity and the 2000 census: recommendations for African American and other black populations in the United States. American Journal of Public Health, 90, 1728-1730. 
Williams, D. R., Neighbors, H. W., \& Jackson, J. S. (2003). Racial/ethnic discrimination and health: findings from community studies. American Journal of Public Health, 93, 200-208.

Williams, D. R., \& Williams-Morris, R. (2000). Racism and mental health: The African American experience. Ethnicity \& Health, 5, 243-268.

Williams, D. R., Yu, Y., Jackson, J. S., \& Anderson, N. B. (1997). Racial differences in physical and mental health:
Socio-economic status, stress and discrimination. Journal of Health Psychology, 2, 335-351.

Willie, C. V., Kramer, B. M., \& Brown, B. S. (Eds.). (1973). Racism and mental health. Pittsburgh: University of Pittsburgh Press.

Yen, I. H., Ragland, D. R., Greiner, B. A., \& Fisher, J. M. (1999). Racial discrimination and alcohol-related behavior in urban transit operators: Findings from the San Francisco Muni Health and Safety Study. Public Health Reports, 114, 448-458. 